Article

\title{
Fields and Facebook: Ta'ayush's Grassroots Activism and Archiving the Peace that Will Have Come in Israel/Palestine
}

\author{
Jon Simons
}

Media School, Indiana University, Bloomington, IN 47405, USA, E-Mail: simonsj@indiana.edu

Submitted: 7 July 2015 | Accepted: 23 November 2015 | Published: 18 February 2016

\begin{abstract}
Israeli peace activism has increasingly taken place on new media, as in the case of the grassroots anti-Occupation group, Ta'ayush. What is the significance of Ta'ayush's work on the ground and online for peace? This article considers the former in the light of social movement scholarship on peacebuilding, and the latter in light of new media scholarship on social movements. Each of those approaches suggest that $T a^{\prime}$ ayush has very limited success in achieving its strategic goals or generating outrage about the Occupation in the virtual/public sphere. Yet, Ta'ayush's apparent "failure" according to standard criteria of success misses the significance of Ta'ayush's work. Its combination of grassroots activism and online documentation of its work in confronting the Occupation in partnership with Palestinians has assembled an impressive archive. Through the lens of Walter Benjamin's philosophy of history, Ta'ayush can be seen to enact a "future perfect" peace that will have come.
\end{abstract}

\section{Keywords}

archive; Israel; media activism; new media; Palestine; peace activism; social media; Ta'ayush; Umm el-Arayes; Walter Benjamin

Issue

This article is part of the issue "Peacebuilding in the Age of New Media", edited by Vladimir Bratic (Hollins University, USA).

(C) 2016 by the author; licensee Cogitatio (Lisbon, Portugal). This article is licensed under a Creative Commons Attribution 4.0 International License (CC BY).

\section{Introduction: A Small Incident in the South Hebron Hills}

On the YouTube channel of guybo111 there is a 47 second video (guybo111, 2013a). The clip shows a melee of Israeli soldiers, activists and locals. Above the noise an activist can be heard shouting in Hebrew to one soldier, "You're kicking a girl!" to another who is grabbing a boy "Leave the boy alone!", and to another who approaches him as he films "leave the camera alone and calm down." As of June $28^{\text {th }} 2015$, the video had attracted 2961 views, 4 likes, 4 dislikes, and 4 shares. A separate video (guybo111, 2013b) lasting 42 seconds, shows in slow motion a woman activist being attacked by a settler who grabs her camera and smashes it, amid much shouting. This video was posted on November $23^{\text {rd }} 2013$ to the Facebook page of Guy Butavia, who is an activist in Ta'ayush, a grassroots group of "Israelis \& Palestinians striving together to end the Israeli occupation and to achieve full civil equality through daily non-violent direct-action" (Ta'ayush, 2015a). The four line Hebrew text on the post protests that settlers grabbed and smashed an activist's camera while Israeli soldiers looked on, and then arrested her and another activist, along with 5 Palestinians. The English text reads: "Ta'ayush activist been attacked and her camera smashed by settlers 23 11 2013", and contains the hyperlink to the video. The video posting has 19 likes and 24 shares.

Both videos of this routinely violent incident, one of many that characterize and sustain the Israeli Occupation of the West Bank, can also be found in a report of the day's activities on Ta'ayush's website (Ta'ayush, 2013a). The text (which is translated from Hebrew into English) explains that preceding the recorded incident Palestinian children of families on whose land the doubly illegal (in international as well as Israeli law) outpost of Mitzpe Yair had been attacked by the settlers. The children had approached hothouses built by settlers and scheduled for demolition by order of the Is- 
raeli High Court. The report continues in indignant tone to add that the soldiers present did not intervene for about twenty minutes, during which some of the Palestinians were injured and the activist's camera broken. Then the soldiers began enforcing a "closed military area" order, roughly arresting two Israeli activists and 15 of the Palestinians (including children), most of who were blindfolded and bound, and some of whom were beaten while under arrest. 10 minors were released on the spot, 2 activists and 5 Palestinians (the landowner and 4 children) were taken to the Israeli police station, from which the activists, who agreed to a restriction order, were released after 2 hours and the Palestinians after 2 days, on payment of bail.

What is the significance of this new media activity for peacebuilding in Israel/Palestine? I will consider several interrelated issues. What is the relationship between the grassroots solidarity activism of $T a^{\prime}$ ayush and their presence on the Internet and social media? How should we understand the online practices of documentation of activism, public exposure of violence by soldiers and settlers, and expressions of outrage about the Occupation? Social movement scholarship, particularly the branch of it that intersects with new (or social) media studies, offers some instructive answers to those questions, which are outlined in what follows. Yet those answers miss the full significance of $T a^{\prime}$ ayush's online presence, especially its website, which, through the lens of Walter Benjamin's philosophy of history, appears as an archive of both the Occupation and of its activities in the "future perfect", prefiguring a time in which the work of the activists will have become recuperated by the practice of peace as partnership. "A future of equality, justice and peace begins today, between us, through concrete, daily actions of solidarity to end the Israeli occupation of the Palestinian territories" (Ta'ayush, 2015a).

\section{Ta'ayush and Anti-Occupation Activism}

Ta'ayush is one of several new activist groups that formed following the October 2000 events that mark the involvement of Palestinian Israelis in the second intifada. The peace camp has changed post-2000: it is more internationalized than previously; more prone to identify with Palestinians and to act in close cooperation with them; more likely to be characterized by nonviolent direct action; and ironically it is operating in an atmosphere in which the very term 'peace' has been discredited, such that activists often see themselves struggling against occupation or for human rights, justice, or such like, and not for peace (Fleischman, 2012; Hallward, 2011; Lamarche, 2009). As my interviewee from Ta'ayush said, "we've lost the discourse of peace". ${ }^{1}$ An additional way in which activism has

${ }^{1}$ Ta'ayush activist interview, Jerusalem, 11/12/2012. changed since 2000 is that the groups have a significant presence on the Internet, through websites and more recently on social media. Hence, the site or public sphere in which peace activism occurs has changed to include not only the "public screen" (DeLuca \& Peebles, 2002) but also the "public/virtual sphere" (Goldberg, 2010).

In place of an overt ideology the group has a "doctrine of a working modality", according to which 'Ta'ayush' expressly means not coexistence but "partnership" or "living in common" (coexistence is a discredited term in this sector of the peace camp, especially for the Palestinians) (Zackem \& Halevi, 2004). Ta'ayush have no declared position on a preferred political settlement although, according to one document, in early $2002 \mathrm{Ta}^{\prime}$ ayush activists were committed to a return to the 1967 borders and a just solution to the Palestinian refugee issue (Hermann, 2009, p. 193). Rather, the group is open to whoever wishes to participate in its activities. For several years it could count on a few hundred activists each week from around the country, but now is reduced to a single branch in Jerusalem with a couple of dozen regulars. As it is not an NGO, it depends on volunteers and has few resources, being funded by its members to cover some of the costs of the weekly activities, as well as supporters in Israel and beyond. Significantly, this small group currently includes no Palestinian Israeli activists, in contrast to the early years when their presence made Ta'ayush quite distinct in its social make-up compared to most other Israel peace or anti-Occupation activists.

Ta'ayush became known for its convoys of water, food and other supplies into the West Bank at a time when it was quite cut off because of the second intifada (Badawi, 2005; Hallward, 2011). Another notable campaign assisted the return of the villagers of Yanoun after they temporarily abandoned it under intense harassment by the settlers of Itamar in October 2002. By 2004-2005 the group's attention was focused on the separation wall, which involved many demonstrations and the pursuit of claims in the courts (Hallward, 2011; Shulman, 2007; Zackem \& Halevi, 2004). Ta'ayush developed a repertoire of concrete solidarity activities to support Palestinian farmers who faced restrictions on access to their land or harassment by the military or settlers: olive and other crop harvesting, accompanying shepherds, ploughing fields, clearing out buried wells and cave homes, making paths and roads, and so on. It is this sort of activity that continues today in the group's focus on supporting the villagers of the South Hebron Hills area. Early every Saturday morning a handful of Israeli and international activists leave Jerusalem to join with Palestinians in confronting regular, routine violence-denial of access to land, dispersal of flocks, destruction of buildings and arrests, beatings, and so on. They enjoy occasional successes-a ploughed field, a lamb being born, a settler attack de- 
terred, the release of an arrested activist or Palestinian-all of which add up to significant outcomes in Ta'ayush's area of activity. Even if it does not quite constitute "living in common", the activity on the ground still brings Israelis and Palestinians together in the partnership that is the best encapsulation of Ta'ayush's image of peace, which is performed through the direct action and forged in a common language of activism (Badawi, 2005: Hallward, 2011; Sporen, 2001). Their "vision of peace is in what they do" (Hallward, 2011, p. 193), and their concept of peace is in their activity. ${ }^{2}$

However, Ta'ayush's intended equal partnership has not been performed so convincingly within Ta'ayush (out of the public eye), according to previous research. Certainly, activists did speak publicly of democratic, egalitarian, consensual decision-making, the avoidance of patronizing attitudes, and the formation of a collective identity (Badawi, 2005; Sporen, 2001; Zackem \& Halevi, 2004). Yet, the group had no magic formula for dealing with the common problem of trying to practice equality in the face of structural social inequality (Hallward, 2011). It was like trying to live "an egalitarian heterosexual relationship" (Hermann, 2009, p. 195). The group did not develop practices to address the related patterns of unequal power relations between Ashkenazi and Mizrahi Jews, and Jewish and Palestinian Israelis, whose membership fell (Hallward, 2011; Sivan, 2010). There was an exodus from Ta'ayush in October 2006 to establish a new group, Tarabut/Hitchabrut, with a more "domestic" agenda that tries to coordinate socioeconomic struggles within Israel with anti-Occupation activism (Sadovsky, 2007). Other activists became more focused on sustained activity against the separation wall. $^{3}$ As Atalia Omer (2013) observes, in the absence of a discourse of just peace that integrates the subaltern voices of the victims of Euro-Zionism (Israeli Palestinians and Mizrahim), into new, Middle Eastern versions of Judaism and Israeli Jewish identity, the Israeli peace movement suffers from conceptual blindness.

The group has in effect narrowed its purpose to blocking one aspect of the Occupation by enabling the villagers of the South Hebron Hills to remain in place and farm their land, though their overall goal is to end

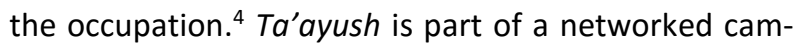
paign of Palestinian, Israeli and international activism with local goals, such as to prevent the expulsion of Palestinians from what the Israeli Occupation authorities define as Firing Zone 918 (Schaeffer Omer-Man, 2013). Other groups with which Ta'ayush networks include Machsom Watch, Rabbis for Human Rights (especially for legal representation), Breaking the Silence, Combatants for Peace, and Settlement Watch (for in-

\footnotetext{
${ }^{2}$ Activist interview.

${ }^{3}$ Activist interview.

${ }^{4}$ Activist interview.
}

formation about the illegal settlements that harass Palestinians and seize land). In addition, members of Ta'ayush are often active in one or more other groups, such as Free Jerusalem Sheikh Jarrah Solidarity and Anarchists Against The Wall. The small group now functions with little internal discussion, as there is agreement about the sort of activity in which it engages. Coordination of weekly activities-decisions about which sites need how many activists to accompany and work with Palestinians - are made on the day by experienced members. The ongoing issues that do invite discussion-often via email to which I do not have access-are about whether Ta'ayush's work has become too humanitarian rather than political, too close to "normalization" which brings Palestinians and Israelis together in co-existence rather than in co-resistance to all forms of oppression of Palestinians (Palestinian Campaign for the Academic and Cultural Boycott of Israel, 2011). Prior periods of intense discussion, such as about whether the separation wall be opposed altogether or whether it should be resisted only insofar as it diverged from the Green Line (the pre-1967 war ceasefire line), had been fractious.

Partnership with Palestinians consists in coordination at three levels: the heads of local council or mayors who mostly confirm that joint activity is not normalization, local popular committees, and individual farmers who contact Ta'ayush directly to ask for support. On the ground, during joint solidarity activities, the local Palestinians decide how far to take resistance each day (such as opposing a "closed military zone" order by being arrested) but as in all issues partnership also involves the Israeli activists expressing their opinions. At the same time, Ta'ayush is committed to non-violent direct action so they only work with Palestinians who accept that, even if they do so for pragmatic rather than principled reasons. Also typical of such radical direct-action oriented groups, within this network Ta'ayush find themselves in the usual dilemma that they recognize as such, namely legitimizing the Occupation by using its judicial affordances to constrain it (waving sheaves of rulings and regulations in the faces of commanders on the ground), while in principle rejecting the injustices of the occupation as a legal system (Lamarche, 2009). ${ }^{5}$

Historically and currently, Ta'ayush meets some of the generally recognized criteria of a peacebuilding organization as understood in the confluence of social and peace studies. It engages in the transformation and construction of relationships and partnership processes, awareness raising about the Occupation and human rights abuses, and constructive, non-violent confrontation with the Occupation authorities and settlers (Hallward, 2011). It practices active, sustained partnership, and challenges "socio-political power ar-

\footnotetext{
${ }^{5}$ Activist interview.
} 
rangements between Israeli troops and unarmed protestors" (Hallward, 2011, p. 98) and between the Israeli "civilian" (settler) population and Palestinian citizens. Ta'ayush's partnership with West Bank Palestinians is a challenge to the national solidarity of Jewish Israelis propounded and practiced by the Zionist mainstream, especially when they confront the Israeli military. Such confrontation and antagonism to the mainstream is inevitable when the mainstream flows against anything recognizable as "transformative peace", or "just peace", as is the case in Israel. To not confront would not be "peaceful" but mean settling for the current status quo of "no peace, no war" under which Occupation thrives.

Equally significant in Hallward's analysis of contemporary peace activism are Ta'ayush's moves towards reconstitution of boundary identities constructed through narratives of conflict, by engaging in "contentious performances" that challenge those boundaries (Hallward, 2011, p. 21). Literally, the group mixes Jewish Israelis with West Bank Palestinians on the ground, but at the same time they treat the Green Line as a boundary between nationally-defined areas, thereby maintaining distinct identities. It is also important for the Ta'ayush activists to be acknowledged as Israelis, even when their Palestinian partners might prefer to identify them as internationals. ${ }^{6}$ There is only so far that Ta'ayush goes toward transforming the structural violence that undergirds the Palestinian-Israeli conflict and the Occupation in particular. They cross the boundaries of conflictual identities only to some extent. They consider themselves to be an "Arab-Jewish" partnership which, as Omer (2013) points out, means that they implicitly rule out the category of Arab Jews, and thus do not challenge the Orientalist, ethnocentric character of "Euro-Zionism" in which Mizrahi Jews as well as Palestinian Arabs are subjected to Ashkenazi dominance. The Occupation endures, and the peace of Israeli-Palestinian partnership seems elusive. Hallward concludes by observing "the inadequacy of such efforts when conducted on a small scale absent an overall strategy for undermining the regime's 'pillars of support'" (Hallward, 2011, p. 104). Yet one must ask: what is the ethical position of the social movement scholar who judges activism to be "inadequate"? Inadequate in relation to what? Such a judgment assumes an instrumentalist notion of activism that serves a purpose in a "progressive" theory of history. Walter Benjamin proposes a different theory of history through which the significance of activism is not revealed by relating the present to the future, but to the promise encountered in the past. I will turn to Benjamin following the next section of the essay.

\section{Ta'ayush as Media Activism}

If Ta'ayush's grassroots activism is not enough, does its

${ }^{6}$ Activist interview. online presence (which is not covered by Hallward) give us a brighter picture of its peacebuilding efforts? Scholarship on social movements and new, social media suggests that online activism might well contribute significantly to its peacebuilding activities of constructing relationships and processes of partnership, raising awareness of Occupation and human rights abuses, and constructive, non-violent confrontation with the Occupation authorities and settlers. Gamson and Wolsfeld (1993) argued that social movements "need news media for three major purposes: mobilization, validation and scope enlargement" (p. 116), each of which has changed and become more complex with the advent of new media (Tufecki, 2013). Using Facebook and YouTube as low-cost means to mobilize members is significant for large movements, but less so for small groups such as Ta'ayush, whose activity is also exposed to audiences hostile to its work. New media afford activists wider reach to recruit new members and disseminate their work, especially when such dissemination goes viral. Yet, enlargement of scope is constrained by the degree of external validation, or legitimacy. New media give activists the chance to bypass traditional news media that act as the gatekeepers of hegemonic, legitimate public action. Yet this does not mean that publics who have access to new media consider counter-hegemonic activism to be valid, a point which is all too pertinent for anti-occupation work in the eyes of Jewish-Israeli publics. In the light of some scholarship about social movements and new media, I will consider the possibility that online presence boosts the grassroots activism of $T a^{\prime}$ ayush in relation to three interrelated issues: (1) online activism as a complement to the practice of partnership on the ground; (2) social media as widely shared public expression of moral outrage about the Occupation; (3) online presence as providing access for marginalized voices to document the Occupation.

Paolo Gerbaudo (2012) considers social media primarily as a "means...to choreograph collective action [through]...symbolic construction of public space which facilitates and guides physical assembling" (p. 5), which entails the interaction of "mediated communication and physical gatherings" (p. 2). Especially promising is the "personal character of social media and their everyday use as a means of maintaining diffuse spheres of friendship" to construct a "sense of togetherness" (p. 14). Manuel Castells (2012) credits Internet networks with the creation of "togetherness" (p. 225) and facilitating "a form of shared practice" (p. 227), but only insofar as "the social movement is constructed as a hybrid space between the Internet social networks and the occupied urban space" (p. 11). According to Zizi Papacharissi (2015), online storytelling generates affective attachments that do not actually create communities among those not participating directly, but do produce "feelings of community" (p. 9), however fleeting, 
which may "support connective but not necessarily collective action" (p. 128). New media also facilitate the sustenance of shared identity and community within groups as they can frame their activities according to their own anti-hegemonic political discourse (unlike in mass media). Yet, such internal focus can come at the cost of "homophilious sorting", meaning that only those within the activist community's frame of mind participate in a form of online partnership (Tufecki, 2013). To sum up, social media could be a space in which Ta'ayush practice Palestinian-Israeli partnership as a complement to their grassroots activism (which is concentrated on one day per week). It might also be a space in which Ta'ayush share their sense of partnership with a broader public, thereby increasing awareness and possibly recruiting more activists. Or not.

Gerbaudo (2012) argues that social media can serve as "emotional conduits" which bring together "individual sentiments of indignation, anger, pride, and a sense of shared victimhood and transform them into political passions" (p. 14). Manuel Castells (2012) also holds that social movements (whether online or not) "require an emotional mobilization triggered by outrage against blatant injustice" (p. 220) and that Internet networks facilitate the contagious, "viral character of the diffusion of messages" (p. 224). "Multimodal, digital networks are an "effective communication channel" in which people can identify with the anger of others and "transform their anger into action" (p. 15). Papacharissi (2015) focuses on the affective character of social media: "affective publics" are "networked public formations that are mobilized and connected or disconnected through expressions of sentiment" (p. 125). Affective intensity and civic engagement can take the form of liking a post on Facebook, and "structures of feeling" develop around the circulation of YouTube videos (p. 116). Through new media's particular forms of storytelling people can feel their way into politics as they share and immerse themselves in hybrid streams of facts and opinion. Networked publics involve "a generalized expression of indignation, discontent, or disagreement with...regimes" (p. 119). Although Jewish Israelis and Palestinians are by no means victims of the Occupation in the same way, $T a^{\prime}$ ayush's activists share moral anger and outrage about the Occupation as they engage in committed and arduous political action in their solidarity with Palestinian farmers and villagers. Such indignation could be communicated to a connected, affective public who like and share the group's postings on social media. Yet, such indignation may remain the currency of a small counter-public who frame the Israeli occupation in terms of injustice rather than according to the hegemonic framing of security.

Given that $T a^{\prime}$ ayush faces an uphill struggle for validation in the Israeli public sphere, do social media afford an enlargement of scope? Gerbaudo (2012) mentions that new media are significant for social movements as a means of representing the group, eliciting external attention, and as citizen journalism. Papacharissi (2015) points to the online media's ability to give voice to marginalized voices, thereby pluralizing the public sphere. Castells (2012) emphasizes the autonomy of communication through social networks that have immense reach and speed, although Gerbaudo's (2012) observation that social media have replaced the self-managed Internet of the antiglobalization movement should remind us that there is a pay-off between operating in corporate, algorithmically structured social media geared towards the monetization of attention, and their capacity to reach people globally and instantly (Goldberg, 2010). Through activity in the online public sphere, $T a^{\prime}$ ayush also practices citizen journalism that documents not only its own activities but, as in the example with which this essay opens, the actions of the Occupation regime it wishes to bring to an end. Yet it is not the most obvious new media outlet to turn to for such reporting, in contrast to the human rights group $B^{\prime} T$ selem. The documenting of violence by $T a^{\prime}$ ayush, whether routine or exceptional, is an expression of outrage. Public exposure of violence is a form of activism in itself, one that contributes to the archiving not only of Occupation, but also of the peace, the partnership, that will have come.

What characterizes Ta'ayush's online presence? On Ta'ayush's Facebook page (created on October $31^{\text {st }}$ 2009 , and as of July $1^{\text {st }} 2015$, showing 4,280 "likes"), there are posts (roughly one per day) about the group's activities and campaigns. There are also many reports and announcements of activities from similar antioccupation grassroots groups and news items that are reposted, all of which may be in Hebrew or English, or a mixture. The Facebook page is linked to a Twitter account, set up on August $8^{\text {th }}$ 2009, which had 2,422 followers and 2,844 Tweets by July $1^{\text {st }} 2015$, which link back to the posts on Facebook, rather than being "real time" updates as activities occur. Videos of activities are mostly hosted on activist Guy Butavia's YouTube channel, guybo111, which (as of July $1^{\text {st }} 2015$ ) had 1,058 subscribers, hosts 812 videos, (many of which are of $T a^{\prime}$ ayush activities) and has attracted 1,463,345 views in total since November $28^{\text {th }}$, 2007. That relatively large figure indicates the significance of persistent media activity, rather than focusing on the occasional viral success.

There are not Facebook posts for each weekly activity, and hence not an accumulative chronicle of the group's work on this platform. Often when there is a report (as on April $26^{\text {th }}$ 2013) there is an album of photos without captions, in this case 17 of them, and it is hard to figure out what happened without a good deal of local knowledge. The post shows 9 likes, one share, and no comments, with the shares coming from a mixture of locals (with Hebrew and Arabic names) and internationals. Those numbers are not untypical, sug- 
gesting that $T a^{\prime}$ ayush is part of a small homophilous network.

The report for the activity on June $15^{\text {th }} 2013$ is a 2:28 minute video titled (in English) "Settler from Otniel attacking shepherds flocks and activists 15.6.2013" in a post which reads (in Hebrew): "Today, on the land of Umm el Ammad adjoining Otniel. A settler armed with a pistol trespasses on private Palestinian land, attacks a shepherd and activists and threatens to expel the flock. All this happens in open view of the soldiers who don't stop him and in the end shake his hand." The post has 10 likes and 3 shares, while the video had 1,131 views as of June $28^{\text {th }} 2015$. The video shows a good example of Ta'ayush's work: the activists try to put themselves between the settler (who does not speak to them) and the flock, demand that he stop, and call on the soldiers to get him off the land. The video documents the settler's aggression, his cursing and pushing of the Palestinian shepherd who challenges him verbally, and the soldiers' indulgence of his actions before gently escorting him away. Although there is a title at the end in English asking for donations, the dialogue in the clip is in Hebrew and Arabic. In general, Ta'ayush's Facebook posts about activities offer little by the way of contextualization and are frequently sparse with words, allowing the pictures to do the talking.

Ta'ayush (2015b) also maintains a website (updated in 2009) with Hebrew and English, but not Arabic versions. The home page includes an activity spotlight and links to sign up for alerts, get involved with the grassroots activity, donate, and follow Ta'ayush on Facebook and Twitter. There is significant variation of content in the Hebrew and English pages, which seems to depend on who wrote it rather than any significant difference in emphasis or focus. The pages are accessed through the usual banners at the top of each page, about pressing issues, activity spotlights, activities, issue and facts. The banner at the top of each page includes the logo ( $T a^{\prime}$ ayush written in Hebrew, English and Arabic, as well as the phrase "Arab-Jewish partnership") and a short description of the group: "Israelis and Palestinians striving together to end the Israeli occupation and to achieve full civil equality through daily non-violent direct-action" with "since 2000" appended in the Hebrew version. Each of the pages linked to the home page generally feature blog-style reports on activities, with longer pieces from other media, groups or individuals in the "background material" section. Through the activities page one can access an archive of activities organized by year, according to type of activity (agricultural, aid and solidarity, information, protests), and by location, each of which is further subdivided. I will return to this archive below.

To return to the three categories of online presence outlined above, Ta'ayush's activity in the hybrid space of the electronic public sphere is perhaps more of a supplement than a complement to its grassroots work.
The Facebook page does share some partnership with a very limited circle of followers by reporting on ways in which those in the know, such as regular activists who could not participate one week or previous local or international activists, get a sense of what went on and are affirmed in their commitment to the group. Anyone who is somewhat familiar with Ta'ayush is likely to understand from the photo album of the April $26^{\text {th }}$ 2013 activity that soldiers blocked the local Palestinians from grazing on their land, that the $T a^{\prime}$ ayush activists documented it (and probably argued with the soldiers), and that on this occasion the settler who is seen in one photo remained at a distance. Just another Saturday in the South Hebron Hills, just the routine, militarily-enforced denial of agricultural livelihood and access to land. But the Facebook page does not coordinate activity between activists or with Palestinians, which is done by activists visiting locals and by (smart)phone. It does situate the group in a network of other groups whose posts are shared on Ta'ayush's page, but does not facilitate connective action with a broader public or serve for recruitment of new members. The group initially developed on the basis of personal contacts, between some Jewish Israelis and Palestinian Israelis, and more recently when an effort was made to increase the number of activists, it was on the basis of personal networks. ${ }^{7}$ Ta'ayush's website would $^{\prime}$ also be a pathway to learning more about Ta'ayush and anti-Occupation activism, but as such it does not build connective community.

One could conceive of an online, ongoing conversation between the activists and their Palestinian partners that complemented partnership on the ground with a shared practice of togetherness online. But it would have to overcome the language barrier (between Hebrew and Arabic) and something of a digital and social divide between the mostly urban and middle-class Israelis and the mostly rural Palestinians, and would require resources that the group simply does not have. It would need to remain a conversation about activities and the ongoing situation of Occupation rather than becoming a dialogue for dialogue's sake, a model of "coexistence" which has been discredited for failing to acknowledge power asymmetries between Israelis and Palestinians that must be addressed by political transformation (Kampf, 2012). Moreover, emphasis on online activity runs counter to Ta'ayush's ethos of working with their hands and each other on the ground, in a network where the raison d'être of each group is its distinct type of activity. ${ }^{8}$

Ta'ayush's online presence certainly expresses outrage about the Occupation and its many injustices. For the most part, the photographs and videos posted by Ta'ayush highlight the oppressive character of the Oc-

\footnotetext{
${ }^{7}$ Activist interview.

8 Activist interview.
} 
cupation, such as harassment of people and animals by settlers, obstruction of daily life, destruction of property, and arrest. The video for the event on June $15^{\text {th }} 2013$, along with the limited commentary, clearly does so (especially for those who know that Otniel is an illegal settlement and understand the general dynamic of settlermilitary collusion against Palestinian residents in Area C). As suggested above, so too does the album of photographs, but for a much more limited online community. The YouTube videos and Facebook posts, along with the website blog report of the incident described at the start of this essay, definitely involve the intense affect that is expressed as anger about the routine violence.

At the same time, the sharing of indignation is not generated by the online activity but expresses preexisting political passion. Moreover, the communication of anger about the Occupation by $T a^{\prime}$ ayush and the other groups with which it networks is not a sentiment that is widely shared by the Jewish Israeli public (Hermann, 2009). For the most part the routine violence and abuse that prompts indignation is of little interest to the mainstream news media, and hence social media serve as an alternative to rather than competitor with them. Ta'ayush's voice is marginalized in the Israeli public sphere, so social media is a vital outlet for them, as was demonstrated forcibly by an affair in January 2016.

A well-regarded documentary program on Israel's Channel 2 aired a report, based on footage provided by a right-wing group which had planted a couple of its members in $T a^{\prime}$ ayush. The item, which sensationalized $T a^{\prime}$ ayush as if it were some sort of dangerous, secretive organization, included a potentially damning segment in which a key Ta'ayush activist, Ezra Nawi, appeared to boast about having reported Palestinians who had sold land to settlers to the Palestinian Authority's security service, who would rough up and kill the sellers (Ha'aretz, 2016). A media furor followed the broadcast, and Nawi, a Palestinian activist Nasser Nawajah, and later Butavia, were detained in prison by the Israeli police on various charges, including conspiracy to murder. Subsequently they were released without charge by the court which was unimpressed by the police's inability to find any evidence in support of the charges (Hasson, 2016). Some newspaper and alternative online reports that followed the story as it fizzled out went some way towards dispelling the smear of Nawi, Ta'ayush and human rights activists in general (Sheizaf, 2016). Access to social media enabled Ta'ayush, which found itself in the public eye briefly, to tell its own story about the dire situation for Palestinians and its work in the South Hebron Hills. A series of well-produced videos made by volunteers on its Facebook page (Ta'ayush, 2016) had over 25,000 views by February $12016 . .^{9}$ Ta'ayush practiced citizen journalism and made public its voice that was not only marginalized but also vilified.

${ }^{9}$ Email from activist, February $1^{\text {st }} 2016$.
Yet, Ta'ayush's indignant voice does not snowball into a growing movement. Their sentiments are not contagious and their feeling does not go viral. Currently, Ta'ayush considers the Jewish Israeli public to be a less important address than either Palestinian or international publics. ${ }^{10}$ In the past the group had a media coordinator (Sporen, 2001), and they still maintain relationships with a few dedicated, politically sympathetic Israeli print journalists who periodically push editorial constraints to disseminate both information and shared anger, as well as frustration. The group's documentation of Occupation as it encounters it in its work and through its online presence is significant, but not in the usual terms that new media scholars have used to analyse online activism.

\section{An Archive of Occupation}

The "about" page of Ta'ayush's (2015b) webpage states: "The activities and the activists of Ta'ayush were always concentrated on field work. Documentation (written or photographic) was and will continue to be secondary to this.... The total amount of activity presented on the site is only a fraction of what has been happening in the field over the years." Given that, it is remarkable how much documentation there is on the website which complements social media activism by providing much more explanation and contextualization. I propose that activist media production of images can also serve as an archive-not only in the present for the researcher (myself) of the past (recent or otherwise), but also as an archive of the "future perfect." Constructing an assemblage of the fragments of activist visual and verbal documentation, online observers can construct a document of activism that prefigures a time in which the work of the activists will have become "successful." In the several years that audiovisual recording has become part and parcel of its repertoire of practice, Ta'ayush has amassed a vast, if fragmentary, archive of evidence of the routine violence of Occupation. The collection of information is a function of when and where activities occur, and which activist was present and was prepared to write a report in Hebrew or English. The structuring of the web archive follows both the localism of activity, in small and often remote places, and the specificity and small scale of types of action. The archive in its totality includes YouTube videos and Facebook postings, so it is spread across several platforms. Web 1.0 complements Web 2.0 in this dispersal of the video and documentary archive.

As I went to Umm el-Arayes (where the videos discussed above were filmed), in December 2012 as a participant observer of $T a^{\prime}$ ayush, I focus on that location in this essay. It is a small Palestinian agricultural community located in the troubled South Hebron Hills area,

${ }^{10}$ Activist interview. 
where the continued existence of some 30 Palestinian villages is threatened by the Israeli occupation. On the English version of the website there are 24 items about Umm el-Arayes from November $17^{\text {th }} 2012$ until May $19^{\text {th }}, 2015$. There is a mixture of 6 video postings with paragraph-long explanations, blogs or other written counts, 10 accompanied by photographs, and three without, including an article from Le Monde about $T a^{\prime}$ ayush. On Umm al-Arayes, the Hebrew version has 14 items from $26^{\text {th }}$ January 2013 until January $27^{\text {th }}$ 2015, of which 6 are videos with explanations, 6 are texts with photographs, and 1 is text only (the article from Le Monde). An additional video clip in the Hebrew version is a 5-minute report from Israeli Social TV (2013) about events at Umm el-Arayes. As noted above, the website provides more information than the records of activities on the Facebook page and the YouTube videos, as in the case of the incident on November $23^{\text {rd }}, 2013$. Without the website and its narrative framing, it is hard to fathom what is going, especially for those who understand neither Hebrew nor Arabic, which suggests that the purpose and effect of $T a^{\prime}$ 'ayush's online presence is affirmation of the group and of the network of anti-Occupation activism within which it works, rather than the networking of a large, affective public.

The pattern of settler violence and military and police coercion in relation to local Palestinians and activists runs through Ta'ayush's archive, the coverage of Umm el-Arayes not showing the worst of it. In a longer clip (lasting 8:34 minutes), the heated exchanges between soldiers and Said Awad, the leading local Palestinian campaigner for his family's land rights, the structural violence underlying the whole situation is articulated (Ta'ayush, 2013b). The video starts with members of the Awad family making yet another attempt to reach their land that has been seized by the settlers of Mitzpe Yair. They are blocked by Israeli soldiers wielding a "closed military area" order (which in this case is invalid, as the camera shows it hasn't been completed properly). There is some pushing and shouting, but it's not really the physical and verbal violence that is significant here, nor even the detention of the two activists that is mentioned in the paragraph of text, which in this case does provide useful, concise context for the local situation. Rather, what stands out is Said Awad's determined dispute with the soldier whom he faces almost eyeball to eyeball. Said tells the soldier that he cannot claim to be a "man of the law" as he's defending an illegal settlement. "Your weapon is your law," he says.

The story is not always one of confrontation, though the context is. In one clip hosted on another activist YouTube channel, publicamir, we see the usual cat and mouse game between soldiers trying to enforce a "closed military area" and in this case a Palestinian boy who evades them and manages to reach a settler boy about his age who, after some hesitation, accepts his outstretched hand to shake it. There is no happy ending, regrettably. The settler boy throws a couple of rocks as the Palestinian boy heads back across the field to his family, an act of violence that a nearby soldier appears not to notice (Ta'ayush, 2013c).

The most popular of the 6 clips is the most harrowing. On a tense day at Umm el-Arayes on January $19^{\text {th }}$ 2013 , in enforcing the routine closure order, the military and police arrested 15 local Palestinians and activists, among them a mother and her 18-month-old baby

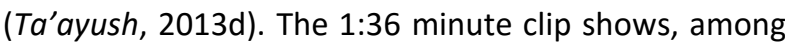
much shouting and shrieking, a man being forced to the floor as he's arrested, and military policy surrounding the woman. They gesture and call for her to be quiet and calm down as they seize her and lead her away, with her baby in her arms, while another activist holds a crying boy. The text on the web page adds some information about the release of the detainees, and on this occasion the video on guybo111 is accompanied by some explanatory text that names the mother as Reema and the baby as Quamar. This clip, credited to Nissim Mossek (who also has his own YouTube channel with material about $T a^{\prime}$ ayush), has had 95,021 views. While in this case the video wasn't posted to the Facebook page, there was a small album of 6 photos documenting Reema's arrest as well as two postings in Hebrew about the event, and subsequently a link to a report in the quality Israeli newspaper, Ha'aretz (2013). On this occasion, Ta'ayush's social media activism broke through to the mainstream press, although not because of a deliberate effort to break media routines.

Although the $T a^{\prime}$ ayush activists have neither the time nor resources to develop the archive beyond the well-organized web site, it can be a rich source for storytelling about activism and Occupation. Israel's Social TV is an NGO that focuses on social justice and human rights issues and activism, broadcasting biweekly on a local channel and through the internet, including its YouTube channel. In October 2013 the station compiled a report, mentioned above, on Umm el-Arayes that used a significant amount of $T a^{\prime}$ ayush footage, including of Reema's arrest in January. For the Palestinians of Umm el-Arayes and the activists, the violence and coercion witnessed in this footage has become routine. While this alternative news video report provides some narrative framing, there is a bigger picture that cannot be told even with the combination of video clips and voice-overs. A more ambitious editing and framing project, such as the documentary film Wild West Hebron (Mossek, 2013) locates local struggles in the larger context of occupation and settlement, by weaving together footage taken over nine years into a complex narrative. In this case, it is not new media alone that is capable of telling the story (Papacharissi 2015, p. 4), but a hybrid of new and alternative media.

$T a^{\prime}$ ayush's new media also blend with old media. 
Among the 24 items on Ta'ayush's English website about Umm el-Arayes are 11 blogs by David Shulman, a veteran activist. These blogs offer a poetic, phenomenological account of many events. His accounts of earlier Ta'ayush (and other) activities have been collected into a memoir that has been published in Hebrew, English and French (Shulman, 2007). His report of harvesting wheat at Jibna, May 2002, blends Biblical associations to the Book of Ruth, description of the landscape, self-awareness of a city-dwelling professor learning how to use a sickle, the discomfort of a tractor ride, the looming danger that Israeli courts will order the local Palestinians from their land, a visit to a cave dwelling filtered through his experience of India, and then a feeling of "fury" at the "malice [that] drives this campaign to uproot the few thousand cave dwellers with their babies and lambs" (p. 23). Here, in old media, in the relationship between an author, his experience and reflection on it, and his readers, is the storytelling with the affective intensity of the expression of outrage that reaches and touches a broader public. Indeed, Shulman's poetic, phenomenological voice offers the tenor in which the significance of Ta'ayush's activity can be heard far more clearly than it can through the filters of social movement and new media scholarship. And so in the final section of this essay I switch away from the tones of social scientific discourse to a style that is open to the peace that will have come.

\section{An Archive of the Peace That Will Have Come}

What does it matter if $T a^{\prime}$ ayush has documented the Occupation if it has achieved only small successes that relieve only some of its worst symptoms for some of the occupied? What does it matter that in its social media presence it expresses outrage, documents abuse, reinforces its activists' commitment, if the public it shares with remains so limited? Why does $T a^{\prime}$ 'ayush's vision of peace as the practice of partnership matter if they realize that they have "lost the discourse of peace almost entirely", if it feels almost impossible to effect change through internal pressure on the Israeli government, if along with the successes there are failures even in the small things, such as saving one village from being cut off by the separation wall? ${ }^{11}$ It matters in part because the small successes have significant local impact. As the activist I interviewed wrote in response to the first draft of this paper:

"I base my feeling of success rather than failure on the fact that whereas in all area $C$ there is a welldocumented process of forcing Palestinians to abandon their land and leave to areas $B$ and $A$, in South Mt. Hebron the process is reversed. There had been a massive expulsion of the Palestinian

11 Activist interview population in this area around 1999 and 2000, but since then, in part, perhaps because of the sort of things we do there, about $50 \%$ of those who left, have returned to their original dwellings and fields, and this process continues before our eyes from week to week". ${ }^{12}$

Moreover, by the time of writing, Said Awad, a landowner from Umm el-Arayes mentioned above, had regained access to two thirds of his land, reflecting the effectiveness of persistent, grass-roots local activity based on Israeli-Palestinian, and international, partnership.

Yet the Occupation remains, with few signs that any more Jewish Israelis are becoming outraged about it than there were before $T a^{\prime}$ ayush became active as part of a broader network of anti-Occupation groups. The coercion of occupation wins nearly every round of the unevenly matched contest. The settlement of Mitzpe Yair still stands, protected by the Israeli army, and the story of Umm el-Arayes is untold in the mainstream media, unheard and unseen in the media space occupied by corporations and governments. Yet even in light of such "strategic" failure, it is too soon to conclude that Ta'ayush has failed, because to do so ignores how week in, week out, it practices peace on the ground, and because the routine criteria of failure and success, which are reflected in much academic scholarship, are insensitive to the uncertain practice of peacebuilding in the face of overwhelming oppression. According to a different, messianic conception of time as expressed by Walter Benjamin, the success or effectiveness of Ta'ayush's activism cannot yet be assessed.

Benjamin is probably best known to readers of this journal from his "artwork" essay in which he discusses the decline of the aura of artworks and development of new media and modes of perception (Benjamin, 2002). He remains ambivalent about the loss of aura under capitalist conditions of media production, hoping that something of aura's use value could be recuperated under not yet existent, revolutionary conditions, which can only be glimpsed in "figures of collective dreams" that appear in certain art such as Dada that creates "a demand whose hour of full satisfaction has not yet come" (p. 18). Benjamin's philosophy of history is of non-linear time, and similarly the political activity of $\mathrm{Ta}^{\prime}$ ayush satisfies a demand for peace that has not yet come.

History (and hence a history of peace activism) does not unfold in a linear fashion, in which "there is causal connection between various moments in history", and in which Ta'ayush's activism (along with that of others) leads to peace, but rather their activism becomes "historical posthumously" (Benjamin, 1968, p. 263). What matters is invisible to a perspective of success that works in terms of cause and effect and a temporal framework of "before" and "after", according to which

\footnotetext{
${ }^{12}$ Email correspondence with Ta'ayush activist, July $13^{\text {th }} 2015$.
} 
the action of Ta'ayush and others should produce a progressive end. The historical time in which $T a^{\prime}$ ayush operates is not a series of consequential events according to which activism succeeds, but is "encountered...as a monad" (p. 263), that is, a point in historical time which is not "a transition, but in which time stands still and has come to a stop" (p. 262). This point, which is filled with the "presence of now" is also "the sign of a Messianic cessation of happening" that interrupts the Occupation as "state of emergency" which is "not the exception but the rule" (Benjamin, 1968, pp. 261-263). As Arik Ascherman (2009) of Rabbis for Human Rights is wont to say: "we never know what little act we will take that seems meaningless, pointless, irrelevant, useless at the time-but whether that will be the act that tips the scales one way or the other." Similarly, (but in the different context of queer theory) Judith Halberstam (2011, p. 120) writes: "all our failures combined might just be enough, if we practice them well, to bring down the winner". In activism, "every second of time... [can be] the strait gate through which the Messiah might enter" (Benjamin, 1968, p. 264). Ta'ayush's strategic failure matters in ways that are not apparent from the perspective of instrumentalist, strategic action.

Within this conception of history and political action, Ta'ayush's social media presence should also not be understood as strategic communication that delivers a message. The main significance of the activity on Facebook, YouTube, their website and elsewhere is of self-documentation that adds up to a vital archive, even if not neatly wrapped up in a documentary genre. Their archive takes its place in what Azoulay (Azoulay \& Flanders, 2012, p. 18) refers to as a "public archive" to which neither the state nor private ownership can deny access to "common documents". In these documents viewers can not only see "the strong imposing their will upon the weak" but also "reconstruct violence as a bond of sorts," which in the case of Ta'ayush is a bond of partnership in the face of violence.

The archive is an odd assemblage-it doesn't add up into a whole in an obvious way, but consists of individually fragmentary or incoherent parts, as in Walter Benjamin's Arcades Project, which he conceived of as history in the form of "literary montage" (Benjamin, 1999, p. 460). Rather like rags for Benjamin, Ta'ayush give us a montage - a photo album without captions, a video clip without context, a website without much traffic, an alternative news report with little traction. Yet it is none the less an archive of facts and feelings (Cvetkovich, 2003), not one that tells the whole story, but one in which an image of civil partnership is revealed for those who are open to it. Clearly, for now most of the Jewish Israeli public is not open to assembling $T a^{\prime}$ ayush's archive into something akin to the dialectical image, the "lightning flashes", that Benjamin hoped would form a "constellation of awakening"
(Benjamin, 1999, p. 456, p. 458). The history documented in Ta'ayush's archive is one that few demand to read in the present, but will want to read in a time of peace that will have come.

The video and photographic documentation of Ta'ayush's multiple acts of civil partnership also matters in that it stakes a claim in a mediated public space that the forces of occupation, and the forces that stand behind them, seek to occupy completely, but cannot (Azoulay, n.d.). The occupation forces aim towards dispossession, dispersal and eviction. In contrast, Ta'ayush's archive shows a sharing of space, a dwelling in moments of partnership that will always be there, and so will always be here. On the fields of Umm elArayes, the activists of $T a^{\prime}$ ayush and Palestinians who refuse to be enemies fashion a new body politic, speak a new civil language, and create each week an "open civil area" (as opposed to a "closed military zone").

Until events interrupt the progressive course of history, we will see only fragments of an archive, but one day it will have become apparent that it is an archive of the "future perfect." There will be a time in which the work of the activists will have become recuperated for the past and in the present. Then we will see that the archive is showing us the practice of peace all alongpeace as partnership, as civil togetherness, as embodied reclamation of the land in which such relationships can flourish. Ta'ayush's activism and its archive of dispossession, occupation and repression prefigure the civil partnership whose existence will have become established as it is documented in the present.

\section{Acknowledgements}

I would like to thank the Lady Davis Trust for a fellowship that funded my field work in the autumn of 2012, during a sabbatical granted by Indiana University, Bloomington. I would also like to thank the Jewish Studies Program at Indiana University for supplemental funding for my research, and Norma Musi for her research assistance. This article is based on presentations at the Association of Israel Studies conference in June 2013 and the Bloomington Jewish Studies Program in October 2013, and I thank those present for their instructive comments on each occasion. I am also grateful to the activists of Ta'ayush who welcomed me to their activity and to the people of Umm el-Arayes who allowed me on to their land.

\section{Conflict of Interests}

The author declares no conflict of interests.

\section{References}

Ascherman, A. (2009). Interview with Arik Ascherman. Just Vision. Retrieved from http://www.justvision. 
org/portrait/847/interview

Azoulay, A., \& Flanders, E. (2012). The right to share the public archive: A conversation about Ariella Azoulay's different ways not to say deportation. Fillip, 16, pp. 16-19.

Badawi, K. (2005). Interview with Khulood Badawi. Just Vision. Retrieved from http://www.justvision.org/ portrait/833/interview

Benjamin, W. (1968). Theses on the philosophy of history. In H. Arendt (Ed.), Illuminations. New York: Schocken.

Benjamin, W. (1999). The Arcades project. Cambridge, MA: Harvard University Press.

Benjamin, W. (2002.) The work of art in the age of its technological reproducibility: Second version. In $\mathrm{H}$. Eiland \& M. Jennings (Eds.), Selected writings: Volume 3, 1935-1938. Cambridge, MA: Belknap Press.

Castels, M. (2012). Networks of outrage and hope: Social movements in the internet age. Cambridge: Polity Press.

Cvetkovich, A. (2003). An archive of feelings: Trauma, sexuality, and lesbian public cultures. Durham: Duke University Press.

DeLuca, K., \& Peebles, J. (2002). From public sphere to public screen: Democracy, activism, and the 'violence' of Seattle. Critical Studies in Communication, 19(2), 125-151.

Fleischman, L. (2012). Alternative voices: The transformation of the Israeli peace movement since the Second Intifada. Unpublished paper.

Gamson, W., \& Wolsfeld, G. (1993). Movements and media as interacting system. Annals of the American Academy of Political and Social Science, 528, 114125.

Gerbaudo, P. (2012). Tweets and the streets: Social media and contemporary activism. London: Pluto Press.

Goldberg, G. (2010). Rethinking the public/virtual sphere: The problem with participation. New Media \& Society, 13(5), 739-754.

Guybo111. (2013a). Settlers and other occupation forces violence towards Palestinians and activists 231113. Youtube. Retrieved from https://www.youtube.com/ watch?v=4VPjd1AQEg8

Guybo111. (2013b). Ta'ayush activist been attacked and her camera smashed by settlers $23 \quad 112013$. Youtube. Retrieved from https://www.youtube.com/ watch?v=WY9wfyoS2uw

Hasson, N. (2016, January 31). Left activists Ezra Nawi and Guy Butavia barred from West Bank for two weeks. Ha'aretz. Retrieved from http://www.haa retz.co.il/news/law/1.2834988

Ha'aretz. (2013, January 19). Palestinian youth injured severely by IDF fire near Bethlehem. Retrieved from http://www.haaretz.co.il/news/politics/1.1910172

Ha'aretz. (2016, January 8). Israeli Ta'ayush activist documented attempting to hand over Palestinian who tried to sell land to Jews. [Hebrew] Retrieved from http://www.haaretz.co.il/news/politics/1.2817960

Halberstam, J. (2011). The queer art of failure. Durham: Duke University Press.

Hallward, M. C. (2011). Struggling for a just peace: Israeli and Palestinian activism in the second intifada. Gainesville, FL: University of Florida Press.

Hermann, T. (2009). The Israeli peace movement: A shattered dream. Cambridge: Cambridge University Press.

Kampf, R. (2012). Internet, conflict and dialogue: The Israeli case. In G. Doron \& A. Lev-On (Eds.), New media, politics and society in Israel. London: New York Routledge.

Lamarche, K. (2009). Political activism and legitimacy in Israel: Four groups between cooperation and transgression. In E. Marteu (Ed.), Civil organizations and protest movements in Israel: Mobilization around the Israeli-Palestinian conflict (pp. 73-90). New York: Palgrave Macmillan.

Mossek, N. (2013). Wild West Hebron. Israel/Palestine. Retrieved from https://vimeo.com/98703217

Omer, A. (2013). When peace is not enough: How the Israeli peace camp thinks about religion, nationalism, and justice. Chicago: Chicago University Press.

Palestinian Campaign for the Academic and Cultural Boycott of Israel. (2011). Israel's exceptionalism: Normalizing the abnormal. Retrieved from http:// www.pacbi.org/etemplate. php?id=1749

Papacharissi, Z. (2015). Affective publics: Sentiment, technology, and politics. Oxford: Oxford University Press.

Sadovsky, A. (2007). Interview with Amnon Sadovsky. Just Vision. Retrieved from http://www.justvision. org/portrait/97380/interview

Schaeffer Omer-Man, M. (2013, September 2). Israel's High Court sends South Hebron Hills evictions to mediation. +972 blog. Retrieved from http://972mag. com/israels-high-court-sends-south-hebron-hillsevictions-to-mediation/78324

Scheizaf, N. (2016, January 21). It's open season on anyone opposing the occupation. +972 blog. Retrieved from http://972mag.com/its-open-season-on-anyoneopposing-the-occupation/116184/

Shulman, D. (2007). Dark hope: Working for peace in Israel and Palestine. Chicago: University of Chicago Press.

Sivan, B. (2010). Collective identities and boundaries in the movements "Ta'ayush" and "MachsomWatch" [in Hebrew]. Be'er Sheva: Ben Gurion University.

Social TV. (2013). Umm el-Arayes [in Hebrew]. Retrieved from https://www.youtube.com/watch?v=KB-A7njS QKO\&list=UUZARCDxAhgwiktLLOrjLuaA\#t=25

Sporen, A. (2001, October 23). Living in common [In Hebrew]. Indymedia. Retrieved from www.taayush.org/ new/xaimbe1.jpg

Ta'ayush. (2013a). An organized attack in Umm el Ara'is and More. Retrieved from http://www.taayush. 
org/?p=3606

Ta'ayush. (2013b). A soldier using physical and verbal violence in Umm el 'Arais. Retrieved from http:// www.taayush.org/?p=3567

Ta'ayush. (2013c). You shook my hand? I'll throw stones at you! Retrieved from http://www.taayush.org/ $? \mathrm{p}=3544$

Ta'ayush. (2013d). 15 arrested in Umm el-Arayes, among them an 18 month old baby. Retrieved from http://www.taayush.org/?p=3100

Ta'ayush. (2015a). Retrieved from https://www.face book.com/Taayush-\%D7\%AA\%D7\%A2\%D7\%90\%D7\% 99\%D7\%95\%D7\%A9-\%D8\%AA\%D8\%B9\%D8\%A7\%D9
\%8A\%D8\%B4-170738066985/info/?tab=page_info Ta'ayush. (2015b). Ta'ayush. Retrieved from http:// www.taayush.org

Ta'ayush. (2016, February 1). What happens thereSae'ed. Retrieved from https://www.facebook. com/170738066985/videos/10153188356711986/

Tufecki, Z. (2013). "Not This One": Social movements, the attention economy, and microcelebrity networked activism. American Behavioral Scientist, 57(7), 848-870.

Zackem, U., \& Halevi, Y. (2004). Ta'ayush-Arab-Jewish partnership. Peace News, March-May 2004. Retrieved from www.taayush.org/new/2004-pn.jpg

\section{About the Author}

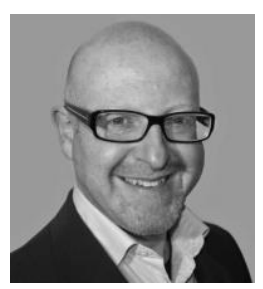

\section{Dr. Jon Simons}

Jon Simons is Associate Professor in the Media School and Department of Political Science, Indiana University, Bloomington. His research and teaching has developed from training in political theory to a focus on the interface between media, social and cultural theory, with a particular interest in political images. His current research is about images of peace in the Israeli peace movement. 